\title{
Pengembangan Media Pembelajaran MEHASAN Untuk Meningkatkan Kemampuan Pemecahan Masalah Siswa Kelas V Sekolah Dasar
}

\author{
Devita Inanda Hernawan*, Yohana Setiawan \\ Universitas Kristern Satya Wacana, Salatiga, Indonesia \\ *email: inandadevita99@gmail.com
}

\begin{abstract}
This research is based on the results of problems in the conventional learning model of mathematics learning. Mathematics lessons make students feel a lack of understanding of the material. Lack of training students in solving story problems, the use of media as a supporting suggestion for the delivery of material. The purpose of this study was to develop MEHASAN learning media to improve the problem-solving abilities of fifth grade elementary school students. This type of research is R\&D research using the ASSURE development model. The research instrument was an expert assessment rubric consisting of a material expert assessment rubric and a media expert assessment rubric. The results of the validation test by material experts get a percentage score of $81.73 \%$ in the very high category. While the results of the validation test by media experts got a score of 79, 68\% with the high category. The results of the feasibility test of the MEHASAN learning media to improve problem-solving abilities, in this case the results of the validation test, are appropriate for the first two things according to the material expert test getting 40 out of 48 and the percentage of $81-100 \%$ with very high category Second, according to the test of media experts, it gets 30 out of 48 and a percentage of $61-80 \%$ with a high category. So it can be concluded that the learning media that has been developed are suitable for use by grade V SD students, especially the material for addition and subtraction of two different denominator fractions.
\end{abstract}

Keywords: Media; Fractions; Elementary Mathematics, Elementary Math Problem Solving

\section{ABSTRAK}

Penelitian ini berdasarkan masalah dalam proses pembelajaran matematika model pembelajaran konvensional. Pelajaran matematika menjadikan siswa merasa kurangnya dalam memahami materi tersebut. Kurangnya melatih siswa dalam memecahkan masalah soal cerita, penggunaan media sebagai saran pendukung penyampaian materi. Tujuan dari penelitian ini adalah untuk pengembangan media pembelajaran MEHASAN untuk meningkatkan kemampuan pemecahan masalah siswa kelas V SD. Jenis penelitian ini penelitian R\&D menggunakan model pengembangan ASSURE. Instrumen penelitian ini berupa rubrik penilaian ahli yang terdiri dari rubrik penilaian ahli materi dan rubrik penilaian ahli media. Hasil uji validasi oleh ahli materi mendapatkan skor presentase 81, 73\% dengan kategori sangat tinggi. Sedangkan hasil uji validasi oleh ahli media mendapatkan skor 79, 68 \% dengan kategori tinggi. Hasil uji validitas kelayakan media pembelajaran MEHASAN untuk meningkatkan kemampuan pemecahan masalah dalam hal ini hasil uji valiadasi kelakayan ada dua hal yang pertama sesuai uji ahli materi mendapatkan mendapatkan 40 dari 48 dan presentase 81 - $100 \%$ dengan kategori sangat tinggi. Kedua sesuai uji ahli media mendapatkan 30 dari 48 dan presentase 61 - $80 \%$ dengan kategori tinggi Sehingga disimpulkan bahwa media pembelajaran yang telah dikembangkan layak untuk digunakan siswa kelas $\mathrm{V}$ SD khususnya materi penjumlahan dan pengurangan dua pecahan penyebut berbeda.

Kata Kunci: Media; Pecahan; Matematika SD, Pemecahan Masalah Matematika SD

Submitted Apr 16, 2021 | Revised Apr 26, 2021 | Accepted Apr 27, 2021

\section{Pendahuluan}

Perkembangan dunia abad ke 21 ditandai dengan memanfaatkan teknologi informasi dan komunikasi di segala macam segi kehidupan, termasuk pada proses pembelajaran. Perkembangan zaman menyebabkan manusia ketergantungan pada produk teknologi informasi yang instant atau siap pakai dan sederhana contohnya yaitu Smartphone. Dalam bidang pendidikan berusaha untuk mewujudkan pembelajaran yang mengikuti perkembangan zaman atau modern karena pesatnya pengguna produk teknologi informasi yang mampu digunakan berbagai golongan usia. Hal ini tentunya akan menjadikan sebuah tantangan bagi semua jenjang sekolah di masa yang akan datang yakni dengan menciptakan lingkungan pendidikan yang mampu meningkatkan kemampuan digital natives yang 
dibutuhkan dalam masyarakat global. Hal ini merupakan hasil dampak positif dari pemanfaatan teknologi yang praktis dan mudah (Smaldino, Lowther \& Russel, 2011).

Bagi tenaga pendidik perkembangan teknologi informasi pendidikan menuntut pendidik untuk melakukan perubahan dan program yang disesuaikan dengan tuntutan zaman (Djaja, 2017). Salah satu teknologi informasi yang dimaksud adalah aplikasi Android yang mampu dimanfaatkan sebagai media pembelajaran. Sisi lain dalam perkembangan yang pesat tersebut juga diiringi oleh beberapa dampak positif dan negatif dari perkembangan teknologi informasi sehingga perlunya memanfaatkan teknologi tersebut dengan baik untuk mengatasi masalah pembelajaran (Abdulhak \& Darmawan, 2013). Selain itu, seiring perkembangan teknologi informasi akan berpengaruh pada gaya, cara, atau metode kegiatan belajar mengajar di masa sekarang dan masa yang akan datang.

Dalam pengamatan penulis media pembelajaran yang digunakan di sekolah saat ini berbentuk seperti audio visual, alat peraga dan benda di lingkungan sekitar. Seiring perkembangan zaman media tersebut kurang menarik bagi peserta didik dan belum memanfaatkan teknologi secara maksimal. Seiring perkembangan zaman dalam penggunaan Smartphone bagi peserta didik di sekolah masih menimbulkan pro dan kontra. Tenaga pendidik dan orang tua masih mengkhawatirkan jika peserta didik tidak konsentrasi belajar akibat membawa Smartphone ke sekolah. Namun, hal tersebut tidak akan terjadi apabila ketika peserta didik mengoperasikan Smartphone dalam pengawasan pendidik atau orang dewasa. Jika dalam proses belajar mengajar mampu memanfaatkan Smartphone maka akan menjadi daya tarik peserta didik untuk semangat belajar, (Nurdyansyah \& Eni Fariyatul Fahyuni, 2016: 2) belajar merupakan proses interaksi pada semua situasi dan kondisi yang berada di sekitar peserta didik, belajar sebagai proses yang terarah untuk mencapai tujuan dan proses berbuat berdasarkan pengalaman yang diciptakan oleh pendidik. Pada dasarnya ciri khas pembelajaran abad ke 21 memusatkan kemampuan peserta didik untuk memiliki kemampuan berpikir kritis, kreativitas, komunikasi, bekerja sama serta kolaborasi untuk memecahkan masalah (Umar, 2018; Redhana, 2019; Widianingsih, 2019). Peserta didik dituntut untuk memiliki keterampilan 4C, yaitu : Critical thinking (berpikir kritis), Communication (komunikasi), Collaboration (kolaborasi), dan Creativity (kreatif) (Septikasari \& Frasandy, 2018; Nahdi, 2019). Salah satu komponen $4 \mathrm{C}$ yang telah disebutkan adalah menyelesaikan masalah disebut dengan pemecahan masalah.

Pemecahan masalah merupakan usaha untuk menemukan jalan keluar dari kesulitan atau masalah yang tidak rutin, sehingga masalah tersebut tidak menjadi masalah lagi (Indarwati, et al., 2014; Wahyudi \& Anugraheni, 2017; Aftriyati \& Roza, 2019). Keterampilan memecahkan masalah dapat melatih peserta didik untuk memahami masalah sehingga akan muncul berbagai ide atau gagasan untuk menemukan sebuah solusi dari permasalahan (Rostika \& Junita, 2017). Jadi dapat disimpulkan bahwa keterampilan memecahkan masalah sangat penting dalam pembelajaran, khususnya pada muatan pembelajaran matematika. Menurut Susanto (2014) matematika adalah disiplin ilmu yang memberikan kontribusi cara memecahkan berbagai masalah kehidupan, serta selalu berjalan berdamingan dengan kehidupan. Maka diharapkan peserta didik mampu memiliki kemampuan memecahkan masalah yang dihadapinya baik masalah terkait pembelajaran matematika ataupun masalah berkaitan dengan kehidupan sehari-hari.

Menurut Polya (Wahyudi \& Anugraheni, 2017) tahapan-tahapan pemecahan masalah terdapat 4 tahapan pemecahan masalah antara lain; memami masalah, merencanakan penyelesaian masalah, menyelesaikan sesuai rencana, dan melakukan pengecekan kembali terhadap langkah-langkah yang telah dikerjakan sebelumnya. Menurut Wahyudi dan Budiono (2012) tahapan-tahapan pemecahan masalah yaitu: 1) Memahami masalah, pada tahapan ini pemecahan masalah diarahkan membantu peserta didik menentukan permasalahan apa saja dan yang ditanyakan dalam soal tersebut. 2) Membuat rencana untuk menyelesaikan masalah, pada tahapan ini ketika memecahkan masalah maka tidak akan berhasil atau menemukann solusi jika tanpa perencanaan yang baik, dalam perencanaan pemecahan masalah peserta didik diarahkan untuk mengidentifikasi strategi atau cara yang tepat dan sesuai untuk 
menyelesaikan masalah. 3) Melaksanakan rencana untuk menyelesaikan masalah, pada tahapan ini peserta didik melaksanakan rencana dan strategi atau cara yang telah ditentukan pada tahapan 1 dan 2 . 4) Memeriksa ulang jawaban yang telah diperoleh, pada tahapan ini peserta didik melakukan pengecekan kembali apakah hasil yang telah diperoleh sudah sesuai dengan ketentuan dan tidak terjadi kontadiksi dengan yang ditanya.

Berdasarkan hasil wawancara penulis terhadap guru kelas 5 di SDN Langensari 04, pendidik kelas tersebut mengatakan bahwa proses pembelajaran matematika masih berpusat kepada guru (teacher center) dengan model pembelajaran konvensional. Dengan mendengarkan pendidik mengajar peserta didik akan menjadi pasif. Selain itu pedidik terbiasa memberikan soal model matematika, peserta didik masih tergantung dengan pendidik dalam memahami materi, khususnya pada muatan pelajaran matematika. Pelajaran matematika menjadikan peserta didik merasa bosan dan takut dalam memahami materi tersebut. ketakutan dan rasa jenuh peserta memberikan dampak terhadap kurangnya melatih peserta didik dalam memecahkan masalah soal cerita. Apalagi pendidik dalam memberikan materi kurang menggunakan media sebagai saran pendukung penyampaian materi. Khususnya untuk anak SD, penggunaan media masih belum begitu banyak dimanfaatkan oleh pendidik. Oleh karena itu, pendidik hendaknya dapat memanfaatkan atau mengembangkan media pembelajaran untuk memberi solusi terhadap kemampuan pemecahan masalah dan memberikan semangat belajar peserta didik dalam memperoleh materi. Kemampuan pemecahan masalah pada matematika, khususnya pada materi penjumlahan dan pengurangan pecahan penyebut berbeda.

Media pembelajaran yang digunakan berupa benda di sekitar sebagai alat peraga yang dimana tidak semua peserta didik bisa mencobanya sendiri sebab keterbatasan jumlah media pembelajaran tersebut. Penggunaan smartphone android sebagai media pembelajaran digunakan untuk browsing tugas, materi saja. Guru kelas 5 SD Langensari 04 mendukung ide media pembelajaran berbasis android jika media pembelajaran tersebut mampu membantu peserta didik untuk meningkatkan kemampuan pemecahan masalah, mampu menarik minat dan perhatian peserta didik. Namun dalam penggunaan smartphone di sekolah tetap dalam pengawasan pendidik sebab kebanyak peserta didik menggunakan smartphone untuk bermain games.

Berdasarkan hasil studi pendahuluan diatas, penulis perlu memberi kontribusi dalam membantu peserta didik memanfaatkan smartphone sebagai media pembelajaran yang di harapkan mampu meningkatkan kemampuan pemecahan masalah peserta didik. Ketika pembelajaran peserta didik diperbolehkan menggunakan smartphone untuk menciptakan kebiasaan dalam memanfaatkan smartphone dalam hal positif. Namun, tetap perlu dibawah pengawasan agar pembelajaran dapat berjalan sesuai dengan tujuan pembelajaran yang telah dirancang. Berdasarkan pertanyaan - pertanyaan tersebut diatas, peneliti akan mengembangkan suatu produk penelitian yakni media pecahan berbasis android (MEHASAN) untuk dapat meningkatkan kemampuan pemecahan masalah peserta didik dengan memanfaatkan smartphone dalam media pembelajaran tersebut. MEHASAN merupakan singkatan dari media pembelajaran pecahan berbasis android. Didalam penggunaanya, peserta didik nantinya akan diajak untuk membuka aplikasi "MEHASAN" terlebih dahulu, tampilan pertama akan disuguhkan petunjuk penggunaan aplikasi, video penjelasan materi pecahan, serta soal. Dengan media ini peserta didik akan lebih semangat, aktif dan tertarik untuk menggunakannya. Dalam media tersebut peneliti merancang media yang berfokus pada materi penjumlahan dan pengurangan dua pecahan dengan penyebut berbeda.

\section{Metode Penelitian}

Penilitian ini dirancang sesuai tujuan yang ingin dicapai yakni menggunakan Research and Development (R\&D). menurut Sukmadinata (2016: 164) menjelaskan Research and Development (R\&D) merupakan sebuah proses dan langkah-langkah untuk mengembangka natau menciptakan suatu produk baik produk hardware maupun produk software yang dapat dipertanggungjawabkan. Memilih jenis penelitian 
R\&D dikarenakan akan mengembangkan media pembelajaran berbasis Android. Penelitian pengembangan ini dilakukan menggunakan model pengembangan ASSURE. ASSURE adalah singkatan dariAnalysa Learner, State Objektive, Select Media and Material, Utilize Media and Materials, Require Learner Participation and Evaluate and Revise, Model ASSURE merupakan rencana secara sistematis dengan mengintegrasikan teknologi dan media untuk pembelajaran agar lebih efektif dan bermakna Heinich, Molenda, Russel (2011: 34).

Pelaksanaan pengembangan media pembelajaran MEHASAN untuk meningkatkan kemampuan pemecahan masalah peserta didik kelas V SD dengan model pengembangan ASSURE yakni : Analyse Learner (Analisis Peserta didik), dilakukan analisis terhadap karakteristik peserta didik seperti usia, tingkat pendidikan, pekerjaan, budaya dan social ekonomi. Lalu menganalisis kemampuan awal peserta didik, seperti pengetahuan dan keterampilan peserta didik. Selanjutnya gaya belajar peserta didik, ada tiga gaya belajar yakni gaya belajar visual, gaya belajar auditorial dan gaya belajar kinestetik, gaya belajar ini berhbungan dengan sifat psikologis yang dimiliki peserta didik untuk beradaptasi dengan lingkungan untuk mengetahui tingkat emosionalnya menghadapi lingkungan belajar.

State Objektive (Menetapkan tujuan pembelajaran), tahap ini merumuskan tujuan pembelajaran yang akan dicapai. Untuk hal itu perlu melakukan analisis kurikulum yang di terapkan di sekolah, melakukan analisis kompetensi inti dan kompetensi dasar yang sesuai dengan kurikulum 2013. Tujuan pembelajarannya mengacu pada unsur ABCD yang merupakan singkatan dari Audience yaitu peserta didik. Behavior yaitu perilaku peserta didik dalam proses pembelajaran, Conditionya itu kondisi peserta didik selama pembelajaran, Degree yaitu ukuran angka hasil belajar yang perlu dicapai oleh peserta didik dalam proses pembelajaran. Kemudian untuk memilih metode dan media disesuaikan dengan tujuan yang telah dirancang. Dalam memilih media harus melihat keterampilan peserta didik antara lain afektif, kognitif dan psikomotor.

Select Media and Materials (Memilih media dan materials), dilakukan perlu merencakan secara sistematis supaya pemilihan media tepat dan dapat mencapai tujuan pembelajaran. Pemilihan metode disesuaikan dengan gaya belajar peserta didik seperti diskusi, simulasi, penugasan dan Tanya jawab. Selanjutnya untuk memilih format media seperti media visual, media gerak, dan media cetak. Langkah yang terakhir dalam memilih media dan materi yakni menghasilkan bahan ajar. Pada tahapan ini menentukan format media, menentukan desain awal media, mengembangkan media, menyusun instrumen penilaian media yang digunakan sebagai menilai kualitas dari media yang dikembangkan, mengembangkan media dan merevisi media kemudian media dinyatakan valid dan dapat di uji cobakan.

Utizile Media and Materials (Memanfaatkan media dan bahan ajar), untuk tahapan ini penggunaan media dan bahan ajar. Pendidik mengkondisikan kelas kemudian pendidik minta peserta didik untuk membuka aplikasi MEHASAN lalu peserta didik mengoperasikan media tersebut sesuai petunjuk yang terdapat di dalam aplikasi. Require Learner Participation (Melibatkan peserta didik dalam kegiatan pembelajaran), partisipasi peserta didik dalam pembelajaran diawali dengan kesiapan peserta didik untuk belajar, kemudian pendidik dan peserta didik saling menyapa dan menanyakan kabar. Kegiatan awal pendidik member motivasi, melakukan apersepsi dan menyampaikan tujuan pembelajaran. Kegiatan inti pendidik menyampaikan materi dan kegiatan penutup dengan memberikan peserta didik tugas untuk menguji pemahaman peserta didik tentanng materi yang telah dipelajari. Evaluasi and Revise (Evaluasi dan Revisi), tahapan terakhir dari ASSURE untuk pembelajaran yang efektif adalah evaluasi dan revisi.

Prosedur penelitian yang digunakan dalam penelitian ini menerapkan prosedur Borg and Gall yang telah dimodifikasi dan dikembangkan oleh Sukmadinata (2016: 182-189), terdiri atas tiga tahapan yakni studi pendahuluan, pengembangan produk dan uji produk, meliputi : 1) Studi pendahuluan, tahapan ini terdiri tiga langkah yakni studi kepustakaan, survei lapangan dan draf produk. Studi kepustakaan dalam penelitian ini dengan mengkaji hasil-hasil dari penelitian terdahulu. Studi pendahuluan dilakukan dengan melalui wawancara analisis kebutuhan sekolah dan peserta didik. 2) Pengembangan produk, 
tahapan ini berpegang pada data yang di dapat saat suvei lapangan dan mengacu pada teori, penelitian terhadulu dan penelitian yang relevan kemudian peneliti membuat darf awal produk. Kemudian dilakukan uji ahli. Setelah melakukan uji ahli langkah selanjutnya melakukan uji coba terbatas dan uji coba lebih luas, 3) Uji produk, tahapan ini untuk menguji produk. Dalam penelitian ini uji produk media pembelajaran apakah dapat meningkatkan kemampuan pemecahan masalah matematika oleh peserta didik. Dalam pelaksanaan uji produk dilakukan dengan menggunakan metode penelitian tindakan kelas yang dilaksanakan dengan 2 siklus.

Instrumen penilaian yang digunakan dalam penelitian ini berupa rubrik penilaian ahli, rubrik penilaian ahli tersebut nantinya akan diberikan kepada validator ahli, sedangkan jenis data penelitian yaitu data kualitatif yang diperoleh dari rubrik penilaian ahli pada uji validasi ahli materi dan ahli media. Penelitian ini melibatkan satu uji ahli materi dan satu uji ahli media, data yang telah diperoleh dari uji validasi ahli kemudian dianalisis untuk menjawab apakah media pembelajaran MEHASAN yang dikembangkan sudah dikatakan layak untuk digunakan.

Hasil dari uji validitas materi media pembelajaran MEHASAN untuk meningkatkan kemampuan pemecahan masalah matematika dapat dikatakan layak untuk di uji cobakan apabila presentase minimal mencapai kategori tinggi yaitu $\geq 61 \%$ (Mawardi, 2014: 113).

\section{Hasil dan Pembahasan}

Hasil studi pendahuluan yang dilaksanakan menjawab penelitian pada Bab 1 dengan rincian.

1. Bagaimanakah langkah - langkah pengembangan media pembelajaran "MEHASAN" dalam meningkatkan kemampuan memecahan masalah peserta didik?

2. Seberapa tinggi tingkat kelayakan produk media pembelajaran "MEHASAN" dalam meningkatkan kemampuan memecahan masalah peserta didik?

Setelah dilaksanakan penelitian mendapatkan jawaban dari pertanyaan bagaimaan langkah-langkah pengembangan media pembelajaran "MEHASAN" dalam meningkatkan kemampuan pemecahan masalah peserta didik. Peneliti menggunakan jenis penelitian R\&D menggunakan model pengembangan ASSURE. Pelaksanaan pengembangan media pembelajaran MEHASAN untuk meningkatkan kemampuan pemecahan masalah peserta didik kelas $V$ SD dengan model pengembangan ASSURE yakni;

Analyse Learner (Analisis Peserta didik), pada tahap ini peneliti melakukan wawancara dengan pendidik kela V SD Langensari 04. Berdasarkan hasil wawancara peserta didik kelas V SD mengalami proses pembelajaran matematika masih berpusat kepada guru (teacher center) dengan model pembelajaran konvensional sehingga membuat peserta didik akan menjadi pasif, terbiasa diberikan soal model matematika, akibatnya ketika peserta didik diberikan soal matematika model cerita, akan mengalami kesulitan dalam memahami soal cerita, dan kuragnya penggunaan smartphone android sebagai media pembelajaran. Kemudian penentuan rancangan media pembelajarn disesuaikan dengan gaya belajar peserta didik seperti diskusi, simulasi, penugasan dan Tanya jawab.

State Objectives (Menetapkan Tujuan Pembelajaran), pada tahap ini merumuskan tujuan pembelajaran yang ingin dicapai. Sebelum merumu merumuskan tujuan pembelajaran peneliti melakukan analisis Kompetensi Inti dan Kompetensi Dasar sesuai dengan Kurikulum 2013. Peneliti memilih Kompetensi Dasar berikut:

\begin{tabular}{llll}
\hline Kompetensi Dasar & & \\
\hline 3.1 & Menjelaskan dan melakukan & 4.1 & Menyelesaikan masalah yang berkaitan \\
penjumlahan dan pengurangan dua & dengan penjumlahan dan pengurangan \\
pecahan dengan penyebut berbeda. & dua pecahan dengan penyebut berbeda.
\end{tabular}

Select Method, Media Or Materials (memilih metode, media atau bahan ajar), pada tahapan ini peneliti memilih media yang akan digunakan berupa media pembelajaran berbasis android. Utilize Media 
and Materials (memanfaatkan media dan bahan ajar), pada tahap ini penggunaan media dan bahan ajar. Pendidik mengkondisikan kelas kemudian pendidik minta peserta didik untuk membuka aplikasi MEHASAN lalu peserta didik mengoperasikan media tersebut sesuai petunjuk yang terdapat di dalam aplikasi.

Require Learner Participation (melibatkan peserta didik dalam kegiatan pembelajaran), pada tahap ini partisipasi peserta didik dalam pembelajaran diawali dengan kesiapan peserta didik untuk belajar, kemudian pendidik dan peserta didik saling menyapa dan menanyakan kabar. Kegiatan awal pendidik member motivasi, melakukan apersepsi dan menyampaikan tujuan pembelajaran. Kegiatan inti pendidik menyampaikan materi dengan media pembelajaran MEHASAN, kemudian peserta didik mengerjakan tugas yang diberikan oleh pendidik untuk memahami materi yang disampaikan melalui media MEHASAN.

Evaluate and Revise (evaluasi dan revisi), setelah dilaksanakan pengkajian oleh dosen pembimbing, kemudian media pembelajaran MEHASAN direvisi sesuai dengan saran dan masukan yang diberikan. Setelah selesai, media pembelajaran MEHASAN akan dikaji oleh ahli materi dan ahli media. Ahli materi dan ahli media nantinya akan memberi saran dan masukan dengan tujuan penyempurnaan draf media pembelajaran MEHASAN.

Prosedur penelitian diatas lebih efesien apabila dilaksanakan dengan model pengembangan ASSURE, yakni: 1) Tahapan studi pendahuluan, Pada tahap studi pendahuluan melakukan studi pustaka, survei lapangan dan penyusunan produk draf awal. Pada tahap studi pustaka peneliti melakukan studi melalui jurnal, buku, dan sumber lain yang relevan. Ditemukan permasalah yaitu dibutuhkan media pembelajaran matematika materi pecahan yang sesuai dengan tuntunan perkembangan zaman. Selain itu dibutuhkan media yang mampu menarik minta peserta didik dalam proses pembelajaran dan mampu meningkatkan kemampuan pemecahan masalah matematika. Kemudian dilakukan studi pustaka berkaitan dengan model penelitian dan pengembangan Research and Development (R\&D) dan model pengembangan ASSURE. Pada tahap survei lapangan peneliti mendapatkan informasi mengenai kebutuhan produk. Tahapan ini dilaksanakan melalui kegiatan wawancara dengan guru kelas 5 SDN Langensari 04 terkait proses pembelajaran serta ketersediaan dari sumber belajar yang digunakan untuk mendukung kegiatan proses pembelajaran. Penyusunan draf produk awal peneliti menentukan Kompetensi Dasar(KD), membuat rancangan produk. 2) Tahap pengembangan produk, pada tahapan ini dilaksanakan untuk menguji produk dengan cara uji ahli, penelitian ini melibatkan dua pakar ahli yakni pakar ahli media dan pakar ahli materi. Tujuan dari uji validasi ahli materi untuk mengetahui tingkat validitas, berikut kisi-kisi instrumen validasi ahli materi dijabarkan dari aspek-aspek dapat dilihat pada tabel 1.

Tabel 1. Kisi-kisi Instrumen Ahli materi

\begin{tabular}{|c|c|c|c|}
\hline Aspek & Indikator & $\begin{array}{c}\text { Butir } \\
\text { Pertanyaan }\end{array}$ & Jumlah \\
\hline Kompetensi & Kompeteni Dasar & $1,2,3,4,5,6,7,8$ & 8 \\
\hline \multirow[t]{2}{*}{ Dasar } & $\begin{array}{l}\text { 3.1Menjelaskan dan melakukan penjumlahan } \\
\text { dan pengurangan dua pecahan dengan } \\
\text { penyebut berbeda }\end{array}$ & & \\
\hline & $\begin{array}{l}\text { Kompeteni Dasar } \\
4.1 \text { Menyelesaikan masalah yang berkaitan } \\
\text { dengan penjumlahan dan pengurangan dua } \\
\text { pecahan dengan penyebut berbeda. }\end{array}$ & $\begin{array}{l}9,10,11,12,13, \\
14\end{array}$ & 6 \\
\hline
\end{tabular}

Sedangkan tujuan dari uji validasi ahli media untuk mengetahui tingkat validitas, berikut kisi-kisi instrumen validasi ahli media dijabarkan dari aspek-aspek dapat dilihat pada tabel 2. 
Tabel 2. Kisi-kisi Instrumen Ahli Media

\begin{tabular}{|c|c|}
\hline Aspek & Indikator \\
\hline Android & $\begin{array}{l}\text { Terdapat button dalam MEHASAN } \\
\text { Terdapat list view dalam MEHASAN }\end{array}$ \\
\hline $\begin{array}{l}\text { Komponen } \\
\text { Kemenarikan } \\
\text { Tampilan }\end{array}$ & Lay out \\
\hline Media Pembelajaran & $\begin{array}{l}\text { Menganalisis kebutuhan } \\
\text { Merumuskan standar dan tujuan pendidikan } \\
\text { Melibatkan peserta didik secara aktif }\end{array}$ \\
\hline
\end{tabular}

Sedangkan peneliti mendapatkan jawaban dari pertanyaan seberapa tinggi tingkat kelayakan produk media pembelajaran "MEHASAN" dalam meningkatkan kemampuan memecahan masalah peserta didik. Untuk mengetahui tingkat kelayakan tersebut peneliti membuat instrumen penilaian kemampuan pemecahan masalah menurut polya dengan indikator empat tahapan penyelesaian masalah menurut Polya yaitu: 1) Memahami masalah dengan indikator penilaian; peserta didik mampu menentukan informasi data yang terdapat dalam soal dan peserta didik mampu menentukan apa yang ditanyakan dalam soal. 2) Perencanaan Masalah dengan indikator penilaian; Peserta didik mampu menentukan cara untuk penyelesaian soal. 3) Melaksanakan Perencanaan dengan indikator penilaian; peserta didik mampu melaksanakan perencanaan. 4) Pemeriksaan kembali proses dan hasil dengan indikator penilaian; peserta didik mampu melakukan pengecekan kembali terhadap cara dan hasil yang telah ditemukan. Berikut kisi-kisi instrumen validasi kelayakan media MEHASAN untuk meningkatkan kemampuan pemecahan masalah dijabarkan dari aspek-aspek dapat dilihat pada tabel 3 .

Tabel 3. Kisi-kisi Instrumen kelayakan media MEHASAN untuk meningkatkan kemampuan pemecahan masalah

\begin{tabular}{ll}
\hline \multicolumn{1}{c}{ aspek } & \multicolumn{1}{c}{ Indikator } \\
\hline $\begin{array}{l}\text { Kemampuan } \\
\begin{array}{l}\text { Pemecahan Masalah } \\
\text { menurut Polya } \\
\text { dalam MEHASAN }\end{array}\end{array}$ & $\begin{array}{l}\text { Memahami Masalah } \\
\text { Peserta didik mampu menentukan informasi data yang } \\
\text { terdapat dalam soal. }\end{array}$ \\
& $\begin{array}{l}\text { Peserta didik mampu menentukan apa yang ditanyakan } \\
\text { dalam soal }\end{array}$ \\
& $\begin{array}{l}\text { Perencanaan Masalah } \\
\text { Meserta didik mampu menentukan cara untuk penyelesaian soal }\end{array}$ \\
& $\begin{array}{l}\text { Peserta didik mampu melaksanakan perencanaan } \\
\text { Pemeriksaan Kembali Proses dan Hasil }\end{array}$ \\
& $\begin{array}{l}\text { Peserta didik mampu melakukan pengecekan kembali terhadap } \\
\text { cara dan hasil yang telah ditemukan }\end{array}$ \\
\end{tabular}

Hasil tingkat validitas media pembelajaran MEHASAN untuk meningkatkan kemampuan pemecahan masalah siswa kelas V SD pada tabel 3.

Tabel 4. Hasil Uji Validitas Ahli

\begin{tabular}{ccccc}
\hline Validator & Skor Ideal & Skor Aktual & AP & Kategori \\
\hline Ahli Materi & 84 & 104 & $81,73 \%$ & Sangat Tinggi \\
Ahli Media & 128 & 102 & $79,68 \%$ & Tinggi \\
\hline
\end{tabular}

Hasil uji validitas kelayakan media pembelajaran MEHASAN untuk meningkatkan kemampuan pemecahan masalah dalam hal ini hasil uji valiadasi kelakayak ada dua hal yang pertama sesuai uji ahli materi mendapatkan mendapatkan 40 dari 48 dan presentase 81 - 100 \% dengan kategori sangat tinggi. Kedua sesuai uji ahli media mendapatkan 30 dari 48 dan presentase 61 - $80 \%$ dengan kategori tinggi. 
Kemudian hasil uji validitas ahli materi mendapatkan skor 84 dari 104 dan presentase $81,73 \%$ dengan kategori sangat tinggi. Sedangkan hasil uji validitas ahli media mendapatkan skor 102 dari 128 dan presentase 79,68 \% dengan kategori tinggi dengan kesimpulan media MEHASAN layak digunakan tanpa revisi. Sehingga dapat disimpulkan hasil kategori tersebut dinyatakan bahwa media pembelajaran MEHASAN untuk meningkatkan kemampuan pemecahan masalah siswa kelas V SD layak digunakan.

\section{Simpulan}

Pengembangan media pembelajaran MEHASAN untuk menigkatkan kemampuan pemecahan masalah siswa kelas V SD menggunakan penelitian R\&D, dengan menggunakan model pengembangan ASSURE telah berhasil dikembangkan. Hasil uji validitas ahli materi mendapatkan presentase $81,73 \%$ dengan kategori sangat tinggi. Sedangkan hasil uji validitas ahli media mendapatkan presentase 79,68\% dengan kategori tinggi dengan kategori tinggi dengan kesimpulan media MEHASAN layak digunakan tanpa revisi. Sehingga media pembelajaran MEHASAN untuk meningkatkan kemampuan pemecahan masalah siswa kelas V SD layak digunakan untuk pembelajaran penjumlahan dan pengurangan dua pecahan penyebut berbeda pada siswa kelas V Sekolah Dasar. Perlu ada penelitian lebih lanjut terkait keefektifan media pembelajaran MEHASAN kepasa siswa SD kelas V.

\section{Daftar Pustaka}

Abdulhak, I. \& Darmawan, D. (2013). Teknologi pendidikan. Bandung: PT. Remaja Rosdakarya.

Aftriyati, L. W., \& Roza, Y. (2019). Analisis Kemampuan Pemecahan Masalah Berdasarkan Minat Belajar Matematika Siswa Sma Pekanbaru Pada Materi Spltv. Jurnal Matematika, Statistika dan Komputasi, 16(2), 226-240.

Djaja, S. (2017). Harapan dan tantangan guru pembelajar moda daring. Jurnal Pendidikan Ekonomi: Jurnal Ilmiah Ilmu Pendidikan, Ilmu Ekonomi dan Ilmu Sosial, 10(2).

Heinich, R, Mondela, R. (1993). Instructional Media And The New Tecbnologies Of Instruction. Memillan Publishing.

Ibrahim, A.R. (2019). Implementasi Model Pembelajaran Kooperatif Tipe Team Games Tournamen Pada Pembelajaran Ips Di Sekolah Dasar. Prosiding Seminar Nasional Pendidikan, 1, 1397-1406. Retrieved from https://prosiding.unma.ac.id/index.php/semnasfkip/article/view/204

Indarwati, D., Wahyudi, W., \& Ratu, N. (2014). Peningkatan kemampuan pemecahan masalah matematika melalui penerapan problem based learning untuk siswa kelas V SD. Satya Widja, 30(1), 17-27.

Mawardi, M. (2014). Model Desain Pembelajaran Konsep Dasar PPKn Berbasis Belajar Mandiri Menggunakan Moodle. Kab.Semarang. Widya Sari Press.

Nahdi, D. S. (2019). Keterampilan Matematika Di Abad 21. Jurnal Cakrawala Pendas, 5(2).

Nurdyansyah \& Eni, F. F. (2016). Inovasi model pembelajaran. Sidoarjo: Nizamia Learning Center.

Redhana, I. W. (2019). Mengembangkan keterampilan abad ke-21 dalam pembelajaran kimia. Jurnal Inovasi Pendidikan Kimia, 13(1).

Rostika, D., \& Junita, H. (2017). Peningkatan kemampuan pemecahan masalah siswa SD dalam pembelajaran matematika dengan model diskursus multy representation (DMR). EduHumaniora | Jurnal Pendidikan Dasar Kampus Cibiru, 9(1), 35-46.

Septikasari, R., \& Frasandy, R. N. (2018). Keterampilan 4C Abad 21 dalam Pembelajaran Pendidikan Dasar. Tarbiyah al-Awlad, 8(2), 107-117.

Smaldino \& Lawther \& Russel. (2011). Instructional Technology an Media Learning. Jakarta Kencana Prenada Media Group.

Sukmadinata. (2016). Metode Penelitian Pendidikan. Bandung: PT. Remaja Rosdakarya.

Susanto, A. (2014). Teori belajar dan pembelajaran di Sekolah Dasar. Jakarta: Kencana Prenada Media Grup. 
Umar, M. A. (2018). Penerapan Pendekatan Saintifik dengan Metode Pembelajaran Berbasis Proyek (Project-Based Learning) dalam Materi Ekologi. Bionatural: Jurnal Ilmiab Pendidikan Biologi, 4(2).

Wahyudi, \& Anugraheni, I. (2017). Strategi Pemecahan Masalah Matematika. Salatiga: Satya Wacana University Press.

Wahyudi, \& Budiono. (2012). Pemecahan Masalah Matematika. Salatiga: Widya Sari Press Salatiga.

Widaningsih, I. (2019). Strategi dan Inovasi pembelajaran bahasa indonesia di era revolusi industri 4.0. Sidoarjo: Uwais Inspirasi Indonesia. 